\title{
COMMUNITY SERVICE ON THE IMPROVEMENT OF CLEAN ENVIRONEMENT BASED ON WASTE BANK IN THE SUB-DISTRICT OF BAHARI BELAWAN (PKM Peningkatan Kebersihan Lingkungan Berbasis Bank Sampah di Kelurahan Bahari Belawan)
}

\author{
Mhd. Pujiono ${ }^{1)}$, Budi Agustono ${ }^{2)}$, T. Kassa Rullah Adha ${ }^{3)}$ \\ 1) Faculty of Cultural Studies, Universitas Sumatera Utara, email: mhd.puhjiono@usu.ac.id \\ ${ }^{2)}$ Faculty of Cultural Studies, Universitas Sumatera Utara, email: agustono_budi@yahoo.com \\ ${ }^{3)}$ Faculty of Cultural Studies, Universitas Sumatera Utara, email: kasarullah@ gmail.com
}

\begin{abstract}
The activity of community service on the improvement of area's hygiene in the district of Bahari Belawan is one of the appropriate activities in improving the hygiene and awareness of the people on the importance of keeping their area clean. Within this community service, the team together with Yayasan Fajar Sejahtera (YAFSI) and the government officer Belawan Bahari district have conducted socialization about the importance of hygienity and ways to manage and dump the waste properly. The method utilized is lecturing method, question and answer, demonstration and simulation. The lecturing method and question and aswer used to provide knowledge and theories about a clean environment. The simulation and demonstration method were used in order to train the people to practice what they have received about the management and development of waste bank. After the socialization had been conducted, the community service team has facilitated the waste bank in Bahari Belawan district and assisting the society in managing it. The result of this community service is an increase in awareness from the public regarding the importance of disposing and managing waste and creating economic opportunities from waste through managing plastic waste into economic value items such as paving blocks.
\end{abstract}

Keywords: waste bank, socialization, clean environment, Bahari Belawan distict.

\section{INTRODUCTION}

In every big city in Indonesia, particularly in Medan city, waste has become one of the main problems. Waste is something unused, unfavoured and thrown away which came from the human's activity and is not created by itself (Chandra, 2006). The law about managing the waste is number 18 year 2008 which stipulates that waste is the human's daily activity leftover/ or coming from the natural process.

Medan city produces 2000 tonnage daily (Batubara, 2016) with uncontrolled volume of waste, the effect is: First, the environment gets dirtier and becomes the place for pathogen orgasm and germs grow sporadically and obviously this endangers human's health. Therefore, waste is potentially becoming the carrier of any diseases. Second, the rotten waste will create bad smell and also endanger human's health. Any liquid comes from it potentially pollutes the well, river or soil water. Third, leftover waste can block the sewage system and cause the flood. Fourth, waste collection in big volume needs bigger space, closed and far from the residences. 
From the facts above, it can be assumed that the problem of waste in Medan City occurs not only because the lack of government involvement but also the lack of people awareness. Therefore, the participation of every stakeholder is need in managing the waste so that a clean city and environment can be envisioned. The waste problem is not only government's responsibility but also the people.

The district of Belawan Bahari is one of the sub districts in Medan city that evolves to be a fishermen village, trade and service and also residencies. This district divides into 13 areas. The population reaches 12095 people with $19.15 \%$ of it or 2313 people live in the poverty.

As one of the efforts to increase the awareness of the people about managing and empowering the waste is by creating the waste bank and this waste bank is expected to increase people awareness in managing the waste. Waste bank is the place where people collect and store the waste to one place, the costumers are the people who live nearby and they collect, select and store the waste based on the types of the waste. They also get the saving book where the amount of money they get from exchanging the waste is written and they can retract the money as well just like in conventional and commercial bank.

Waste bank cooperates with plastic and cardboard scavengers so they can also but the waste from the waste bank. Waste bank also works together with organic fertilizer vendor to distribute the organic waste that has turned to be the organic fertilizer (Kholidi, 2012:2). From this explanation, the main activity of this community service is to increase the awareness of the people to keep their environment clean by establishing and conducting the waste bank in the sub district of Bahari Belawan. This community service has also worked with Yayasan Fajar Sejahtera Indonesia (YAFSI) and the government of sub district of Bahari Belawan through the forum of disaster resilient sub district that has conducted many activities in empowering the people and environment. This community service is also a part of the effort to increase people awareness in keeping their environment clean. Having said that, the problems can be formulated as:

1. How to increase people awareness in sub district Bahari Belawan in keeping their environment clean?

2. How to facilitate activities that focus on keeping the environment clean based on waste bank in Bahari Belawan sub district?.

\section{METHODOLOGY}

Socialization and facilitation in this community service involve 30 heads of households resided in Bahari Belawan sub district. The households were being chosen through interviews conducted by Yayasan Fajar Sejahtera Indonesia and Forum Kelurahan Tangguh Bencana Belawan Bahari that have been doing many empowering activities in the area nearby. The 
methods used in the socialization are solve them.

lecturing method, question and answer In order to achieve the method conduct method, simulation and demonstration.

\section{Lecturing Method}

Lecturing method used to emphasize on the efforts od motivating the participants to have their own willingness and increase their understanding in keeping their environment clean and managing the waste.

Discussion Method and Answer and Question Method

These mehods are very important for the participants in order to measure their ability in accepting the explanation about keeping the environment clean

\section{Simulation Method}

According to Depdiknas Definition ( 2005: 133) "simulation method learning is practical method used to develop the participants skills (cognitive and skills)." This method brings one real situation to the activity or classroom due to the difficulties or barriers to do the practical thing in the real situation.

According to Bahri (2006:90) this simulation learning method focuses on showing the participants a process, situation and some objects being learnt, either the real one or the model followed by the oral explanation. Simulation method is very important in order to make the participants enable to apply the theory in the accepted socialization. Through this simulation, it is expected that the participants are also able to identify all the difficulties that appear and explained in the research method, it is necessary to make steps on model learning in the simulation as follow.

\section{Demonstration Model}

According to Nana Sudjana (2010: 121), demonstration model is one of learning methods focuses on the process of something occurred". Syaiful (2007: 210), explains that demonstration model is a show about an occurrence of an event or object.

\section{At Glance about Waste Bank Concept}

Waste bank is one system of collective dry waste management system that encourages people to actively engaged in the activity. This system will collect, separate and distribute economic value added waste to the market so people can have economic benefit by saving the waste. All the activities of this waste bank system are conducted by the people and for the people. Just like conventional bank, waste bank also needs managerial system conducted by the people.

The waste stored by the cosutmers must be separated. This requirement encourages people to do the separation and classification of waste. For example, the separation is based on the material: plastic, paper, glass and metal. Eventually, waste bank will create a new culture amongst the people to separate the waste. Waste bank doesn't only give positive impact to the environment and add economic values to the people, but also create clean culture to appreciate the added 
value on non organic waste around us.

This part will explain steps and mechanism of waste bank establisment, starting from the process of socialization about the waste bank to the people, training of the technical operational of waste bank, determining the standard of the waste bank, running the waste bank system and supervising the operation of waste bank.

The system of waste bank that runs based on the standard is potential to develop well and prosper the people around. Therefore, it is important to learn more about the application of waste bank in the designated area So that this waste bank can be the tool to do the social engineering to build a system of proper waste management in the society.

\section{Classification of waste type}

Household waste, in general is classified into organic and non organic waste. Organic waste is derived from living thing and degradable by nature, for example the leftover food or other organism such as leaves and wood. Non organic waste comes from human's creation such as glass, plastic, paper, metal and etc.

\section{Waste Bank Establishment}

There are five steps of waste bank establishment according to guidance book published by Yayasan Unilever Indonesia (2013):

\section{Initial Socialization}

Initial socialization is important to give introductory and basic knowledge. The discourse delivered is about waste bank as national program, the definition of world bank, the flow of waste management, and income division system.

\section{Technical Training}

When the agreement to establish waste bank is reached, next meeting must be scheduled to set up the detail standard of running a waste bank, the work mechanism and the income management. This training is needed as well to decide the name of the waste bank, the comittees, the location, the scale location, hoarder and the storing timetable.

\section{Waste bank operation}

The operation of the waste bank is determined by the agreed schedule. The officers must be ready with administrative requirements and things such as scaling machine. The costumers come to the waste bank by bringing sorted waste. Costumers will receive money recorder and written in the form of saving book based on the volume of waste that is stored.

\section{Supervision and Evaluation}

Some challenges might appear in the application of the waste bank, the society must keep doing the facilitation during the running system to help the people solving their problems. Evaluation is conducted to make a better waste bank.

\section{Development}

The system of waste bank can be developed to be other units such as credit centre and basic needs centre. The expansion of waste bank function can be adjusted to the 
people need. For example, if most of the residents are entrepeneurs, then the development of the waste bank can be in the form of credit/lending centre.

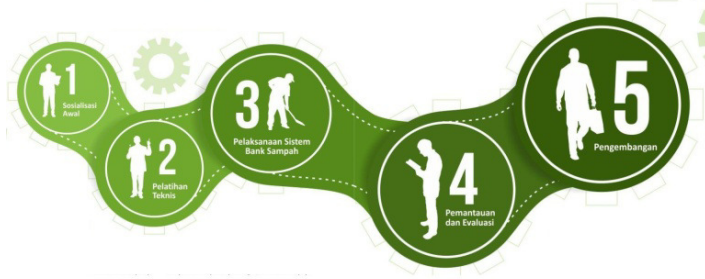

Figures 1. five steps of waste bank establishment

\section{RESULT AND DISCUSSION}

Intially, the community service team together with other foundations were discussing to plan the socialization of waste bank establishment in Bahari Belawan sub district. The discussions have been done twice with Yayasan Fajar Sejahtera Indonesia on the $1^{\text {st }}$ february 2008 in the Faculty of Cultural Studies, Universitas Sumatera Utara, followed by the meeting between government officers from Bahari Belawan sub district and Yayasan Fajar Sejahtera Indonesia in the office of Bahari Belawan sub regency in $22^{\text {nd }}$ February 2018.

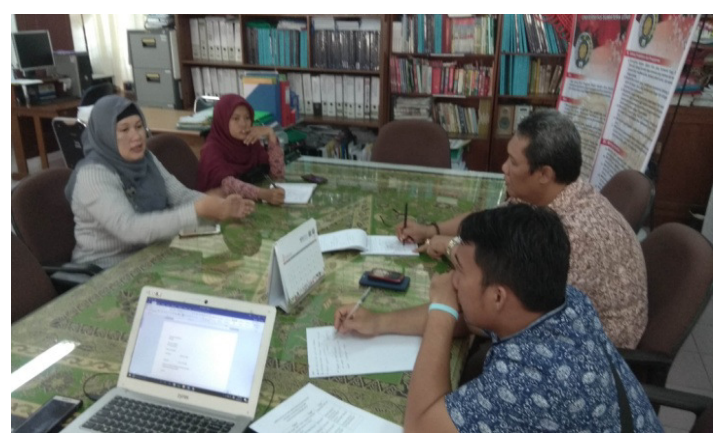

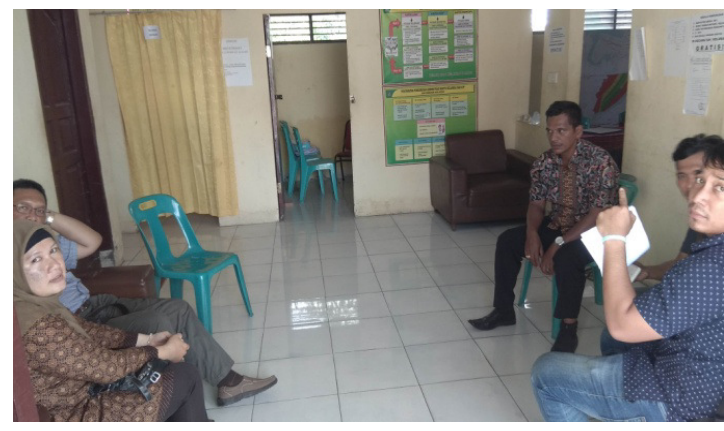

Figure 2. Discussion with YAFSI and Bahari Belawan Sub District

Decisions have been made from the discussion such as the concept of the waste bank and the socialization time table which conducted on $21^{\text {st }}$ may 2018. The targeted participants included 40 people that came from Bahari Belawan sub district, govenrment officers, youth organization where the speaker of this socialization was Mr Supraja, S.Sos. a practitioner in environment whose expertise is on waste management. The second discussion has also come with a decision to observe the current situation of Bahari Belawan sub district. Here are some pictures of the environment in Bahari Belawan sub district.

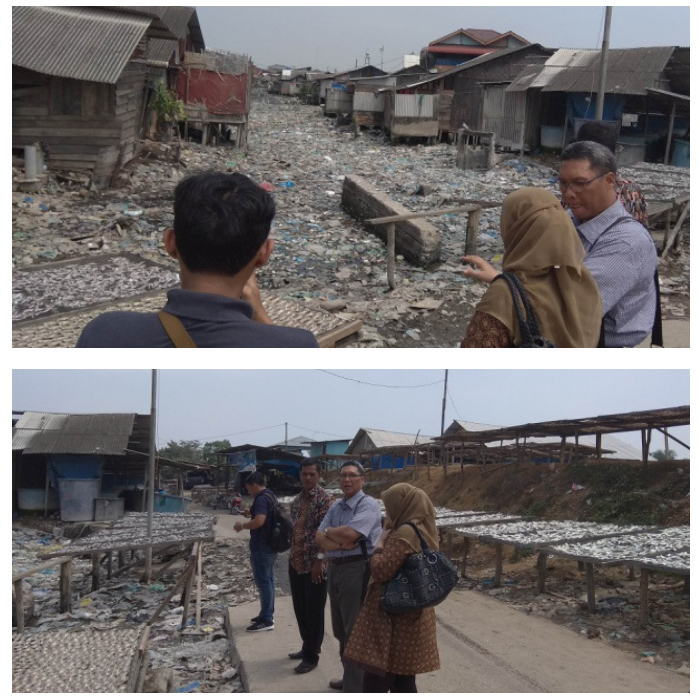

Figure 3. The condition of Bahari Belawan sub district 
The event started with the welcoming speech from the community service team and a speech represented by the officer of Bahari Belawan sub district. The welcoming speech of the community service team signified and emphasized on the opportunity to contribute to the society by working together with related parties either the people and the government officer to establish the waste

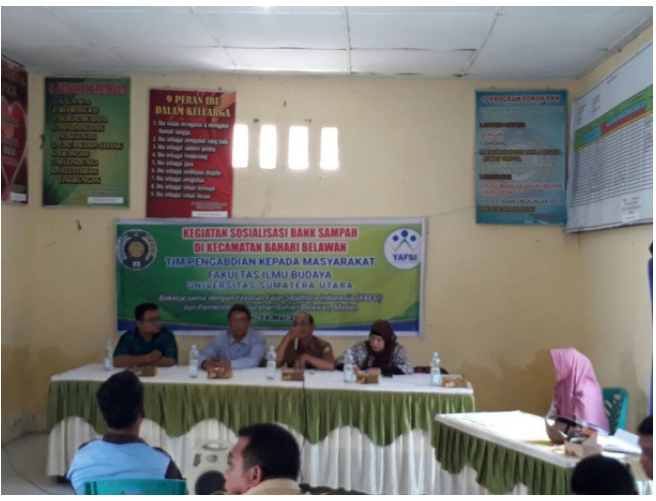

Figure 4. Socialization of Waste Bank bank program. The team also gave a remark that in order to build the awareness of the people to keep the environment clean, they have to work together and create a strong society that aims to clean the area. The next remarks came from Mr. Supraja, S.Sos as an environment practitioner who lecturing about basic concept of keeping the environment clean that is by doing $4 \mathrm{R}$ which stands for reduce, reuse, recyle and replace which eventually connected to the waste bank program such as, the saving system like in the conventional bank, reward system and etc. The participants were enthusiast in listening all the lecturing and activel: engaged in discussion and question an answer session.
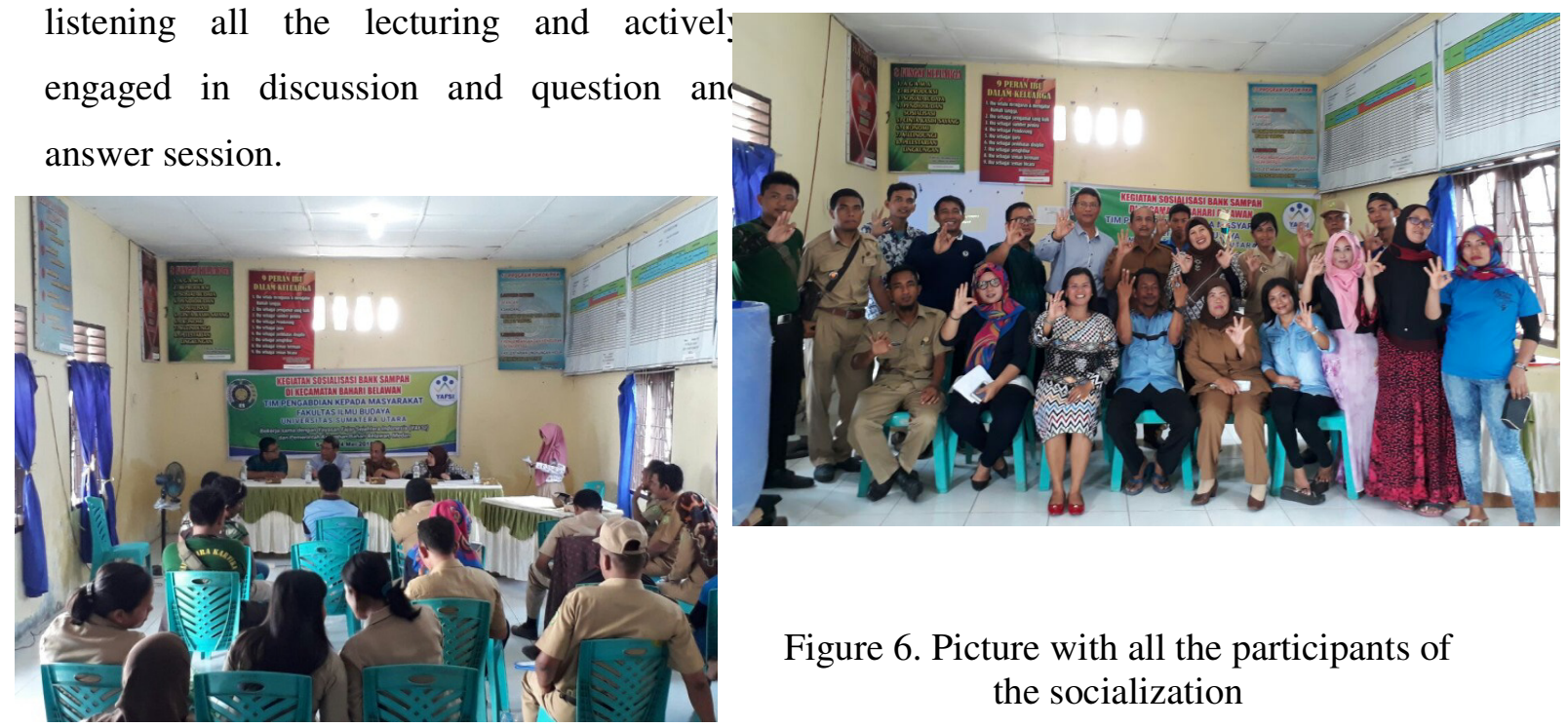

Figure 6. Picture with all the participants of the socialization 
After the socialization ended, the next agenda was symbolic handover of the waste bank toolkit and equipments from the community service team, Faculty of Cultural Studies, Universitas Sumatera Utara to the management of the waste bank which consists of Forum Tanggap Bencana Bahari Belawan sub-district represented by the government officer of Bahari Belawan sub district.

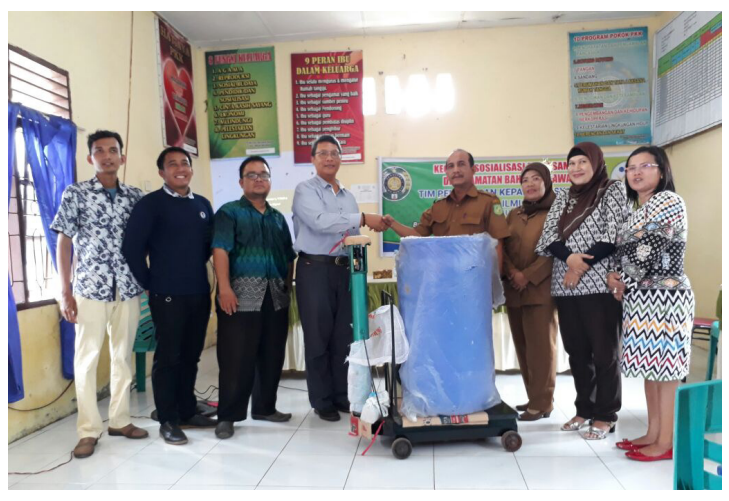

Figure 7. Symbolic Handover of some aids, toolkits and equipments from community service team to the waste bank management

\section{Paving Block from Plastic Waste}

In an effort to assist in improving cleanliness in the Belawan Bahari outflow environment, the community service team of the University of Sumatera Utara has tried to make plastic waste collected in waste banks have benefits from the economic aspects of society. For this reason, after conducting discussions with service partners and asking experts in the field of waste management, the USU community service team sought the utilization of processed plastic waste into paving blocks.

Paving blocks from plastic rubbish are a new thing popular in the creative industry of waste disposal. In the process, the plastic waste that will be processed is melted first. Then, all of the melted base material is put into an iron mold cup that has been adjusted to size. Then wait five minutes until the mold is completely hardened.

The process of making plastic paving blocks is fairly easy, besides the available material is quite a lot, the process is also fairly simple. To produce one block paving, at least three kilograms of dry plastic material is needed. This figure is almost the same as the weight of one paving block produced.

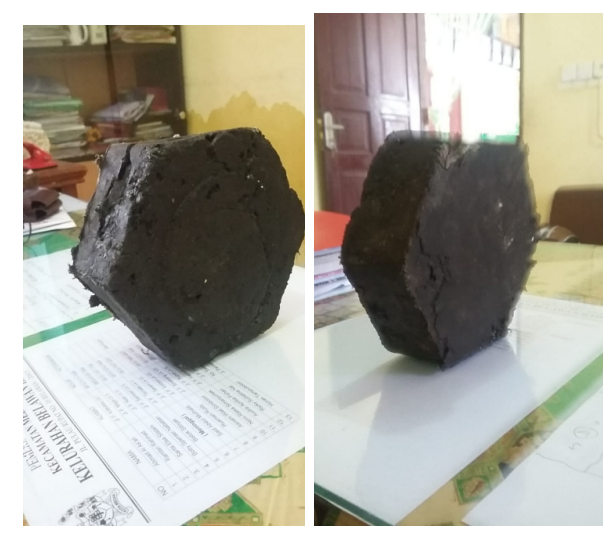

Figure 8. The plastic paving blocks

\section{CONCLUSION}

The effort to grow the awareness of the people to keep their environment clean in Belawan Bahari sub district conducted by the community service team of Faculty of Cultural Studies, Universitas Sumatera Utara is by doing the socialization of cleaning the environment with the emphasize on the establishment of waste bank. The next step is supervision and facilitation in running the 
waste bank program in order to have a more productive and economic added value waste bank. Community service team of faculty of cultural studies Universitas Sumatera Utara has given some assistance and aid to the waste bank by providing the toolkits, equipments and the provision of supervision and facilitation of waste bank in Bahari Belawan sub district, Medan.

\section{SUGGESTION}

Clean environment and waste have always been interrelated and becoming the challenges for many cities in Indonesia. Therefore some efforst need to be taken in order to increase people awareness in keeping their environment clean and managing the waste properly. Society empowerement as the management of the waste bank is one of the solutions that is visible and doable. This apparently can change the way people think that waste can be value added things and have economic value, therefore some creative activities are needed to find out the solution in increasing people awareness keeping their environment clean.

\section{REFFERENCES}

Bahri, Syaiful. 2006. Strategi Belajar Mengajar. Jakarta: Rineka Cipta

Chandra, Budiman. 2006. Pengantar Kesehatan Lingkungan. EGC. Jakarta.

Depdiknas. 2005. Kumpulan Metode Pembelajaran/ Pendampingan. [online]. http.

www.media.diknas.go.id/media/document/ 3553.pdf(10 Mei 2017)

Ecolink. 1996. Istilah Lingkungan Untuk Manajemen. E-dukasi.net, http://www.edukasi.net/pengpop/pp_full.php?ppid=257 $\&$ fname $=$ hal $2 . h t m$.

Hadiwiyoto, S. 1983. Penanganan dan Pemanfaatan Sampah. Yayasan Idayu. Jakarta.

Kholid, Mohammad. 2011. "Pemberdayaan Ekonomi Umat Melalui Pola Kerjasama Bank Sampah”, Skripsi S1 Program Studi Perbankan Syariah UIN Syarif Hidayatullah Jakarta.

Sujdana, Nana. 2010. Penilaian Hasil Proses Belajar Mengajar. Bandung: Remaja Rosdakarya.

Utami, Eka. 2013. Buku Panduan Bank Sampah dan 10 Kiat Sukse. Yayasan Unilever Indonesia : Jakarta

Waluyo, Muji. 2014. In-On-In-On Plus TB Model Peningkatan Kompetensi Supervisi Akademik bagi Kepala Sekolah Binaan di Kabupaten Temanggung. UMYPress

Wianata, Putra, dkk. 2004. strategi Belajar Mengajar. Jakarta: Universitas Terbuka 